\section{Enantioselective Cyclization by a Hexacoordinated Chiral Hydrogen Phosphate}

\section{Key words}

chiral counteranion

phosphates

Pictet-Spenglertype cyclization<smiles></smiles><smiles>CCPCC</smiles><smiles>C1CC2CC3CC1CC(C2)C3</smiles><smiles></smiles>

$\mathrm{R}^{1}=\mathrm{Me}, \mathrm{OMe}, \mathrm{Cl}$

$\mathrm{R}^{2}=$ Alk

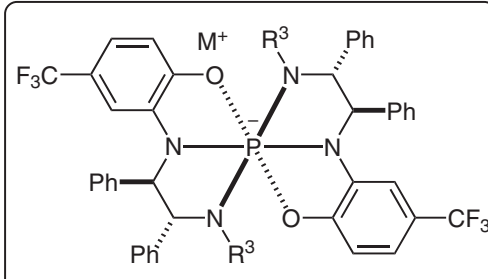

$\mathrm{R}^{3}=3,5-\mathrm{Ph}_{2} \mathrm{C}_{6} \mathrm{H}_{3} \mathrm{CH}_{2}$

$1 \cdot \mathrm{M}$

Selected examples:<smiles>Cc1ccc2c(c1)N[C@H](CCCCCl)c1cccn1-2</smiles>

$88 \%$ yield $\mathrm{er}=93.5: 6.5$<smiles>C=CCCC[C@H]1Nc2cc(C)ccc2-n2cccc21</smiles>

$99 \%$ yield er $=95: 5$<smiles>Clc1ccc2c(c1)N[C@H](CCc1ccc(Br)cc1)c1cccn1-2</smiles>

er $=98: 2$
Significance: The Ooi group reports a PictetSpengler-type cyclization catalyzed by the Brønsted acid $\mathbf{1} \cdot \mathrm{H}$. The presented chiral hexacoordinated phosphate ion consists of two N,N,O-tridentate backbones, including 1,2-diphenylethylenediamine as a readily available chiral source. The catalyst is prepared by deprotonation of a phenol followed by cation exchange. The authors obtained a single-crystal X-ray structure of $\mathbf{1} \cdot \mathrm{HNEt}_{3}$ which confirmed its octahedral $P(V)$ core.
Comment: The authors demonstrate the catalytic activity of $\mathbf{1}$ as hydrogen phosphate. Although the substrate scope is limited, it is noteworthy that the hexacoordinated phosphate can indeed control the enantioselectivity. More mechanistic studies and control experiments would be highly appreciated to further understand and expand the presented transformation. 